\title{
LAPAROSCOPIC SURGERY IN THE DIAGNOSIS AND MANAGEMENT OF HYDROSALPINX IN THE PREPARATION FOR IN VITRO FERTILIZATION PROCEDURE
}

\author{
Jasmina Popović1,2, Dragana Radović-Janošević1,2, Ranko Kutlešić1,2, \\ Sonja Pop-Trajković-Dinić1,2, Milan Trenkić1,2, Dane Krtinić2,3
}

\begin{abstract}
Fallopian tube disease is one of the most common causes of infertility in women that results from tubal damage or obstruction. The American Society for Reproductive Medicine classification, based on scoring system of tubal changes verified by laparoscopy, is most widely used in practice.

The aim of the paper is to determine the involvement and stage of hydrosalpinx and surgical therapy options in patients treated for marital infertility due to tubal factors during the preparation for in vitro fertilization after laparoscopy. In the two-year period, at the Clinic for Gyneacology and Obstetrics, Clinical Center Niš, 75 patients underwent videolaparoscopy to confirm previously established diagnosis of hydrosalpinx. Surgical treatment performed depended on the severity stage of hydrosalpinx. Removed Fallopian tubes were submitted for a histopathological analysis to the Institute of Pathology, Clinical Center Niš.

An early stage hydrosalpinx was diagnosed by laparoscopy in 32 tubes. Out of them, tubal removal was performed in 9 tubes, and reconstructive surgery in 21 . The most conspicuous changes were present in 46 Fallopian tubes. Surgical removal was performed in 41 tubes, occlusion of the isthmic portion of the tube was present in 5 tubes, and no reconstructive surgery was performed (significant correlation $\mathrm{p}<0.001$ between the stage of hydrosalpinx and type of surgery). HP analysis of the removed Fallopian tubes revealed chronic inflammation in $84.27 \%$.

It is necessary to employ always the same, clear criteria in the diagnosis and to select properly the patients who will benefit from hydrosalpinx surgery, either tubal removal or reconstructive surgery.
\end{abstract}

Acta Medica Medianae 2017;56(4):5-10.

Key words: hydrosalpinx, laparoscopy, in vitro fertilization

${ }^{1}$ Clinic of Gyneacology and Obstetrics, Clinical Center Niš, Serbia

${ }^{2}$ University of Niš, Faculty of Medicine, Niš, Serbia

${ }^{3}$ Clinic of Oncology, Clinical Center Niš, Serbia

Contact: Jasmina Popović

Paraćinska 19, 18000 Niš, Srbija

E-mail: jasminap@medfak.ni.ac.rs

\section{Introduction}

Fallopian tube disease (a tubal factor) represents the damage or obstruction of the tubes and is one of the major causes of female infertility responsible for $25-30 \%$ of female infertility cases (1). A tubal factor is an obstruction or damage of the tubes. The most common cause of tubal damage is pelvic inflammatory disease, followed by ectopic pregnancy, endometriosis, and adhesions from previous surgeries in the pelvic area, or after the rupture of the appendix. In 1975, according to Westrom, permanent infertility after one pelvic infection was registered in $11.4 \%$ of cases, after two in $23.13 \%$, and after three or more infections even $54 \%$ of women faced in-fertility (2). Furthermore, the risk of an ectopic pregnancy is 10 times greater after acute salpin-gitis.

Tubal occlusion may involve the proximal part (most commonly caused by endometriosis), mid-part and distal tubal part. Distal tubal occlusions are the most common ones. Distal tubal part is the outer half of the ampulla, together with the infundibulum and fimbria (pavilion) (3). Infectious lesions of the distal tubal part are separated or attached to each other and comprise $70-85 \%$ of the tubal lesions (4-6).

Hydrosalpinx is the result of end-stage salpin-gitis and consequence of distal tubal occlusion. The term comes from the Greek words 'hydro' meaning water and 'salpinx' - meaning tube. Distal tubal occlusion results in hydro-salpinx. There are different criteria for the staging of distal tubal changes. Strandell in his papers from 2000 and 
2001 reported the classification of hydrosalpinx into:

-Hydrosalpinx simplex - represented with excessive distention and thinning of the tubal wall, with flattened and widely separated mucosal folds;

-Hydrosalpinx follicularis - represented without central cavity, and the lumen being broken up into compartments, resulting from fusion of tubal plicae $(6,7)$.

The American Society for Reproductive Medicine (ASMR) classification of hydrosalpinx, using the scoring system of tubal changes verified by laparoscopy, is most widely used in practice and is based on:

-tubal dilation: $>3 \mathrm{~cm} ; 3-5 \mathrm{~cm}$; $<5 \mathrm{~cm}$.

-tubal wall thickness: normal, moderately thickened, thick, and rigid.

-condition of mucosal folds-rugae: $<75 \%$ preserved, 35-75\% preserved, 35\% preserved with mucosal fusion.

-presence and type of adhesions (8).

The presence of hydrosalpinx $(9,10)$ decreases the rate of clinical pregnancies during in vitro fertilization (IVF) procedure. The mechanism of implantation failure is not completely understood. The following explanations have been proposed:

1. The content of tubal fluid is embryotoxic due to the presence of bacterial cultures or other microorganisms, presence of lymphocytes, cytokines, prostaglandins, and catecholamines.

2. Mechanical explanation - the hydrosalpinx fluid washes out the embryos - hydrorrhea.

3. Hydrosalpinx fluid lacks essential nutritional factors, primarily glucose (glucose pyruvateprimary nutrients), necessary for the embryonic development, thus changing endometrial receptivity for embryonic implantation.

4. There is a hypothesis for simultaneous damage to the endometrium caused by inflammatory substances transported via blood or the lymphatic system $(11,12)$.

There are many diagnostics tests for the evaluation of Fallopian tubes: hysterosalpingography (HSG), sonohysterosalpingography (SIS), transvaginal hydrolaparoscopy, videolaparoscopy with salpingoscopy, falloposcopy.

Laparoscopy is the "gold standard" method, enabling direct visualization of the peritoneal cavity. The advantage of this method is the possibility of a continuous treatment of the observed changes.

The aim of the paper was to determine the involvement and stage of hydrosalpinx and surgical therapy options in patients who underwent laparoscopy and were treated for marital infertility due to tubal factors during the preparation for in vitro fertilization.

\section{Material and methods}

In the period of two years (2010 and 2011), 75 patients underwent videolaparoscopy at the
Clinic for Gyneacology and Obstetrics, Clinical Center Niš, to confirm the previously established diagnoses of hydrosalpinx during the preparation for in vitro fertilization. Diagnosed changes in the form of hydrosalpinx were classified as stages IIII. Hydrosalpinx stage I was classified as the Fallopian tube dilated up to $3 \mathrm{~cm}$, with normal wall thickness and over $75 \%$ preserved mucosal folds, without surrounding adhesions; hydrosalpinx stage II as the tube up to $5 \mathrm{~cm}$ in diameter, with moderately thickened wall and with 50- 75\% preserved mucosal folds, with or without surrounding adhesions; and hydrosalpinx stage III was classified as the tube dilated over $5 \mathrm{~cm}$, with a thick wall, and with less than $35 \%$ of preserved mucosal folds, and prominent surrounding adhesions. The patients were divided into four groups according to their age - I group $\leq 30$ years; II group $31-35$ years; III group $36-40$ years; and group IV $\geq 41$ years.

The surgical treatment applied depended on the stage of hydrosalpinx: salpingoneostomy (unilateral, bilateral), salpingectomy (unilateral, bilateral), and tubal occlusion (unilateral, bilateral) using Karl Storz videolaparoscopic apparatus. The removed Fallopian tubes were submitted for histopathological (HP) analysis to the Institute of Pathology, Clinical Center Niš. Statistical data processing was performed electronically. A data base was created in MS Office Excel, and the SPSS 19.0 (Statistical Package for Social Sciences) was used for statistical analysis. Statistically significant differences in the incidence of main characteristics of the studied problems were tested by the Chi Square Test for Independence. The values of 0.05 , 0.01 and 0.001 were considered statistically significant.

\section{Results}

Table 1 shows the distribution of operated patients according to the age and type of infertility treatment.

As illustrated in Table 1 , the majority of patients 40 (53.34\%) were in the age group II, and most of the patients were treated for primary infertility 68 (90.67\%).

In our 75 patients, on video-laparoscopy, we registered 7 missing tubes due to previous surgeries, 24 tubes without changes, and based on these data the stages of hydrosalpinx of 119 Fallopian tubes were shown in Table 2 . The greatest number of tubes (46 - 38.66\%) had the highest stage of damage.

Out of 119 damaged tubes, 2 tubes were inaccessible due to massive adhesions to the surrounding organs, and in 117 tubes different surgical treatments were thus performed, as shown in Table 3, with a comparable age distribution of the patients. Tubal reconstruction was performed in only $19.66 \%$ of the tubes. Since the majority of patients were in the age group II, the greatest number of surgeries were performed in this group. 
Table 1. Distribution of patients according to the age groups and type of infertility treated

\begin{tabular}{|c|c|c|c|c|c|}
\hline \multirow{7}{*}{ Number of patients } & \multicolumn{4}{|c|}{ Age groups } & \multirow{2}{*}{ Total } \\
\hline & $\mathrm{I}$ & II & III & IV & \\
\hline & $\mathrm{N}(\%)$ & $\mathrm{N}(\%)$ & $\mathrm{N}(\%)$ & $\mathrm{N}(\%)$ & $\mathrm{N}(\%)$ \\
\hline & $15(20)$ & $40(53.34)$ & $16(21.33)$ & $4(5.33)$ & \multirow{4}{*}{$75(100)$} \\
\hline & \multicolumn{4}{|c|}{ Type of infertility } & \\
\hline & \multicolumn{2}{|c|}{$\begin{array}{c}\text { Primary } \\
\mathrm{N}(\%)\end{array}$} & \multicolumn{2}{|c|}{$\begin{array}{c}\text { Secondary } \\
\mathrm{N}(\%)\end{array}$} & \\
\hline & \multicolumn{2}{|c|}{$68(90.67)$} & \multicolumn{2}{|c|}{$7(9.33)$} & \\
\hline
\end{tabular}

Table 2. Classification of damaged Fallopian tubes

\begin{tabular}{||c||c|c|c|c||}
\hline \multicolumn{1}{|c|}{} & \multicolumn{3}{|c|}{ Hydrosalpinx stage } & \multirow{2}{*}{ Total } \\
\cline { 2 - 5 } & $\mathrm{I}$ & II & III & $\mathrm{N}(\%)$ \\
\cline { 2 - 5 } & $\mathrm{N}(\%)$ & $\mathrm{N}(\%)$ & $\mathrm{N}(\%)$ & $119(100)$ \\
\hline Number of tubes & $32(26.89)$ & $41(34.45)$ & $46(38.66)$ & 19 \\
\hline
\end{tabular}

Table 3. Type of surgery used for altered tube in relation to age groups

\begin{tabular}{|c|c|c|c|c|c|c|}
\hline \multirow{4}{*}{ Age groups } & \multicolumn{5}{|c|}{ Type of surgery } & \multirow{3}{*}{ Total } \\
\hline & \multirow{2}{*}{$\begin{array}{l}\text { Salpingectomy } \\
\text { unilateral }\end{array}$} & \multirow{2}{*}{$\begin{array}{c}\text { Salpingectomy } \\
\text { bilateral }\end{array}$} & \multirow{2}{*}{$\begin{array}{l}\text { Salpingo- } \\
\text { neostomy }\end{array}$} & \multicolumn{2}{|c|}{ Tubal occlusion } & \\
\hline & & & & unilateral & bilateral & \\
\hline & N (\%) & N (\%) & N (\%) & N (\%) & N (\%) & N (\%) \\
\hline$\leq 30$ & $7(5.98)$ & $6(5.13)$ & $6(5.13)$ & $2(1.71)$ & $2(1.71)$ & $23(19.66)$ \\
\hline $31-35$ & $17(14.53)$ & $24(20.51)$ & $13(11.11)$ & $7(5.98)$ & $2(1.71)$ & $63(53.84)$ \\
\hline $36-40$ & $8(6.84)$ & $6(5.13)$ & $4(3.42)$ & $3(2.56)$ & $4(3.42)$ & $25(21.37)$ \\
\hline$\geq 41$ & $2(1.71)$ & $2(1.71)$ & $0(0)$ & $0(0)$ & $2(1.71)$ & $6(5.13)$ \\
\hline Total & $34(29.06)$ & $38(32.48)$ & $23(19.66)$ & $12(10.25)$ & $10(8.55)$ & $117(100)$ \\
\hline
\end{tabular}

Table 4. Type of surgery used for impaired tubes in relation to hydrosalpinx stage

\begin{tabular}{|c|c|c|c|c|c|}
\hline \multirow{4}{*}{$\begin{array}{l}\text { Hydrosalpinx } \\
\text { stage }\end{array}$} & \multicolumn{4}{|c|}{ Type of surgery } & \multirow{3}{*}{ Total } \\
\hline & \multicolumn{2}{|c|}{ Salpingectomy } & \multirow{2}{*}{$\begin{array}{l}\text { Salpingo- } \\
\text { neostomy }\end{array}$} & \multirow{2}{*}{ Tubal occlusion } & \\
\hline & unilateral & bilateral & & & \\
\hline & N (\%) & N (\%) & N (\%) & N (\%) & N (\%) \\
\hline I & $1(1.68)$ & $8(6.72)$ & $21(17.65)$ & $1(0.84)$ & $32(26.89)$ \\
\hline II & $13(10.92)$ & $10(8.4)$ & $2(1.68)$ & $15(13.45)$ & $40(34.45)$ \\
\hline III & $21(17.65)$ & $20(16.81)$ & $0(0)$ & $5(4.2)$ & $46(38.66)$ \\
\hline Total & $35(30.25)$ & $38(31.93)$ & $23(19.33)$ & $21(18.49)$ & $117(100)$ \\
\hline
\end{tabular}

${ }^{1}$ Salpingectomies integrated (unilateral + bilateral) in calculating the values of $\mathrm{X}^{2}$ test.

Table 5. Type of obstruction of blocked Fallopian tubes

\begin{tabular}{||c||c|c|c|c||}
\hline \multirow{2}{*}{} & \multicolumn{3}{|c||}{ Type of obstruction } & \multirow{2}{*}{ Total } \\
\cline { 2 - 5 } & Hydrosalpinx dex. & Hydrosalpinx sin. & Hydrosalpinx bill. & \\
\cline { 2 - 5 } & $\mathrm{N}(\%)$ & $\mathrm{N}(\%)$ & $\mathrm{N}(\%)$ & $\mathrm{N}(\%)$ \\
\hline Number of tubes & $10(8.4)$ & $23(19.33)$ & $86(72.27)$ & $119(100)$ \\
\hline
\end{tabular}


The most common surgery was bilateral salpingectomy - in 24 tubes (20.51\%).

Table 4 shows the type of surgical procedure used in relation to the stage of obstructed tube change. The least conspicuous stage of hydrosalpinx was diagnosed on laparoscopy in 32 tubes, salpingectomy was performed in 9 tubes, and reconstructive surgery was the most common procedure performed (in 21 tubes - 65.62\%). Out of 46 tubes with most severe changes (hydro-salpinx stage III), surgical removal was performed in 41 tubes, 5 of them occluded in the isthmic portion, and no reconstructive surgery was perfor-med.

The Chi-Square test of independence (with Yeats correction) showed a statistically significant correlation $(p<0.001)$ between the stage of hydrosalpinx and type of surgery, $x^{2}(4, n=119)=$ 74.23.

During the surgical procedure it was observed that the most common changes involved both tubes $-72.27 \%$, as shown in Table 5 .

The results of histopathological (HP) verification of 89 tubes were also analyzed in the study. HP results verified chronic inflammation in 75 tubes $(84.27 \%), 2$ tubes had acute inflammation, and 2 tubes showed subacute inflammation. Endometrial changes were diagnosed in 4 tubes, and 2 tubes were of normal structure, as seen in Table 6.

Table 6. Histopathological findings of the impaired tubes

\begin{tabular}{||c||c|c||}
\hline \hline Histopathological finding & Total & Stage III \\
\hline \hline Salpingitis chronica & 49 & 14 \\
\hline Salpingitis chronica fibrosa & 23 & 11 \\
\hline Salpingitis isthmica nodosa & 2 & 2 \\
\hline $\begin{array}{c}\text { Salpingitis chronica } \\
\text { follicularis }\end{array}$ & 1 & - \\
\hline Hematosalpinx & 1 & 1 \\
\hline Salpingitis acuta & 2 & 1 \\
\hline Hyperema massiva & 2 & 1 \\
\hline Salpingitis subacuta & 2 & 2 \\
\hline Necrosis isthemica & 1 & 1 \\
\hline Endometriosis & 4 & - \\
\hline Normal structure & 2 & - \\
\hline Total & 89 & 33 \\
\hline \hline
\end{tabular}

\section{Discussion}

Out of 75 patients in the experimental group, $60(80 \%)$ patients were over 30 years of age. The majority of patients were in the II age group (40 patients, 53.34\%). The modern lifestyle (pursuit of education, career, use of birth control) has brought women to delay their pregnancy. Decreased fertility results in reduced chances of conceiving naturally and in an increased number of patients seeking IVF treatment.
The majority of our patients were treated for primary infertility. Many authors reported that in recent decades primary infertility has been predominant (up to 60\%) compared to secondary infertility $(1,2,10)$. It is a consequence of modern women's belief that delayed childbearing is normal and safe and that modern reproductive techniques may help them conceive when they think the time is right.

Many studies examined the incidence of hydrosalpinx diagnosed by ultrasound in women who were due to undergo in vitro fertilization procedure. In 2009, Standell reported the prevalence of hydrosalpinx in these patients ranging from $10 \%-13 \%(13)$. Although in vitro fertilization is primarily used in patients with tubal damage, the patients with severe tubal damage, such as hydrosalpinges, were identified as those having significantly lower rate of implantation and pregnancy in comparison to patients with other forms of tubal damage. Meta-analyses have shown that the probability of achieving a delivery in the presence of hydrosalpinx during in vitro fertilization procedure is reduced by half, and the incidence of spontaneous abortion is doubled. The rate of pregnancies in patients with ultrasono-graphically (US) visible hydrosalpinx is $15 \%$, and $31 \%$ in patients with hydrosalpinx not visible by ultra-sound (14). Standell reported in 1999 and 2000 that pregnancy rates in patients with bi-lateral hydrosalpinx were $12 \%$, in contrast to unilateral hydrosalpinx pregnancy rates of $24 \%$.

Given the proper selection of patients with distal tubal occlusion, patients with mild and moderate hydrosalpinx should undergo salpingostomy, but most authors advocate surgical removal of the diseased tubes in patients with severe hydrosalpinx verified by ultrasound (US) (15-17). In patients with a pronounced or bilateral hydrosalpinx, IVF should be advocated in achieving pregnancy $(18,19)$.

Our study showed that laparoscopy was performed to confirm or rule out the presence of hydrosalpinx in the preparation for in vitro fertilization, and corrective or radical surgery was performed depending on the stage of tubal damage. During laparoscopy, the least pronounced hydrosalpinx was diagnosed in 32 tubes, salpingectomy was performed in 9 tubes, and reconstructive surgery in 21 of them. In 46 tubes with the most severe stage III hydrosalpinx, 41 tubes were surgically removed $(89.13 \%), 5$ of them occluded in the isthmic part, and no reconstructive surgery was performed (with an adequate statistical significance).

The results of the HP analysis of the removed $84.27 \%$ chronically inflamed tubes confirm the surgeon's assessment and validity of the decision to take a radical approach during laparoscopy.

\section{Conclusion}

Our two-year study revealed a high involvement of hydrosalpinx in patients with tubal infertility factor who were planned to undergo IVF. 
The authors believe that it is necessary to employ always the same and clear criteria in the diagnosis and management of hydrosalpinx. A proper selection of patients eligible for certain surgical tubal procedure in improving in vitro fertilization treat- ment outcomes is the main duty of a doctor. Further studies are required to show if when hydrosalpinx treatment is concerned, the principle "primum non nocere" can be fully observed.

\section{References}

1. Al Fadhli R, Tulandi T. Tubal disease. U Falkone $T$, Hurd W. Clinical Reproductive Medicine and Surgery. Mosby inc. Phyladelphia, 2007: 609-709.

2. Westrom L. Effect of acute pelvic infalmatory disease on fertility. Am J Obstet Ginecol 1975; 121(5): 707-14. [CrossRef] [PubMed]

3. Vučetić D. Korektivni postupci na jajovodima radi uspostavljanja i održavanja njihove prolaznosti prednosti i nedostaci pojedinih metoda. Doktorska disertacija, Niš, 1988.

4. Hammadieh N, Coomarasamy A, Ola B, Papaioannou S, Afnan M, Sharif K. Ultrasound-guided hydrosalpinx aspiration during oocyte collection improves pregnancy outcome in ivf: a randomized controlled trial. Hum Reprod 2008; 23(5): 1113-7. [CrossRef] [PubMed]

5. Gomel V. Hydrosalpinx. In: Garcia CR, Mastroianni L, Amelar R.D, Dubin L. Current therapy of infertility 1984-1985. Toronto: B.C.Decker Inc. Philadelphia, CV Mosby Company. St Louis. Toronto London, 1984. p. 72-9.

6. Strandell A. Hydrosalpinx - to treat or not. The Second World Congres on Controversies in Obstetrics, Gynecology and Infertility, Paris, 2001; Monduzzi editore, International Proceedings Division: 185-91.

7. Standell A. The influence of hydrosalpings on in vitro fertilisation and embryo transfer. Hum Reprod Update 2000; 6(4): 387-95.

8. Al-Fadhli R,Tulandi T. Tubal Disease. In: Falcone T. Clinical Reproductive Medicine and Surgery. Philadelphia: Mosby; 2007. p. 697-709.

9. Standell A. Lidhard A. Eckerlund I. Cost-effective ness analysis of salpingectomy prior IVF based on randomized controlled trail. Hum Reprod 2005; 20(12): 3284-92. [CrossRef] [PubMed]

10. Camus E, Poncelet C, Goffinet F, Wainer B, Merlet F, Nisand I, et al. Pregnancy rates after in-vitro fertilization in cases of tubal infertility with and without hydrosalpinx: A meta-analysis of published comparative studies. Hum Reprod 1999;14:1243-9. [CrossRef] [PubMed]

11. Ng EH, Chan CC, Tang OS, Ho PC. Comparison of endometrial and subendometrial blood flows among patients with and without hydrosalpings shown on scanning during in vitro fertilization treatment. Fertil Steril 2006; 85(2): 333-8. [CrossRef] [PubMed]

12. Daftary GS, Taylor HS. Hydrosalpinx fluid diminished endometrial cell HOXA 10 expression. Fertil Steril 2002; 78(3): 577-80. [CrossRef] [PubMed]

13. Standell A. Managment of hydrosalpinx. In: Gardner DK, Weissman A, Howles CM, Shoham Z. Textbook of Assisted Reproductive Tehnologies. 3rd ed. Informa healthcare; 2009. p. 778-89.

14. Steinkampf MP, Malizia BA. Assisted Reproductive technology: Clinical aspects. U Falkone T, Hurd W. Clinical Reproductive Medicine and Surgery. Phyladelphia: Mosby inc.; 2007. p. 567-96.

15. Hayes $E$, Rock $J$. When is infertility surgeru indicated. The Third World Congres on Controversies in Obstetrics, Gynecology and Infertility, Washington, 2002; Monduzzi editore, International Proceedings Division: 47-53.

16. De Wit W, Gowrising CJ, Kuik DJ, Lens JW, Schats R. Only hydrosalpinges visible on ultrasound are associated with reduced implantation and pregnancy rates after in-vitro fertilization. Hum Reprod 1998; 13(6): 1696-701. [CrossRef] [PubMed]

17. Strandell $A$, Lindhard $A$, Waldenström $U$, Thorburn J, Janson PO, Hamberger L. Hydrosalpinx and IVF outcome: a prospective, randomized multicentre trial in Scandinavia on salpingectomy prior to IVF. Hum Reprod 1999; 14(11): 2762-9. [PubMed]

18. Anderson AN, Linhard A, Loft A, Ziebe S, Andersen CY. The infertile patient with hydrosalpings-IVF with or without salpingectomy. Hum Reprod 1996; 11(10): 2081-4. [CrossRef] [PubMed]

19. Sharara FI. What effect does hydrosalpings have on assisted reproduction. Hum Reprod 1999; 14(3): 577-8. [CrossRef] [PubMed] 


\title{
DIJAGNOSTIKA I TERAPIJA HIDROSALPINGSA LAPAROSKOPIJOM U OKVIRU PRIPREME ZA POSTUPKE VANTELESNOG OPLOĐENJA
}

\author{
Jasmina Popović1,2, Dragana Radović-Janošević1,2, Ranko Kutlešić1,2, \\ Sonja Pop-Trajković-Dinić1,2, Milan Trenkić1,2, Dane Krtinićc, ${ }^{13}$
}

\author{
${ }^{1}$ Klinika za ginekologiju i akušerstvo, Klinički centar Niš, Srbija \\ 2Univerzitet u Nišu, Medicinski fakultet, Niš, Srbija \\ ${ }^{3}$ Klinika za onkologiju, Klinički centar Niš, Srbija \\ Kontakt: Jasmina Popović \\ Paraćinska 19,Niš, Srbija \\ E-mail: jasminap@medfak.ni.ac.rs
}

Oboljenje jajovoda (tubarni činilac) jedan je od najčešćih uzroka neplodnosti žene i predstavlja oštećenje ili opstrukciju jajovoda. Klasifikacija Američkog društva za reproduktivnu medicinu, koja se bazira na skorovanju promena na jajovodu verifikovanih u toku laparoskopije, najčešće se primenjuje u praksi.

Cilj rada bio je da se kod žena lečenih od neplodnosti u braku zbog tubarnog činioca, a u toku pripreme za postupke vantelesnog oplođenja i kod kojih je urađena laparoskopija, utvrdi zastupljenost i stepen hidrosalpingsa, kao i vrsta operativne terapije.

U periodu od dve godine, u Klinici za ginekologiju i akušerstvo Kliničkog Centra Niš kod 75 bolesnica je urađena videolaparoskopija u cilju potvrde prethodno postavljene dijagnoze hidrosalpingsa. Operativna terapija je primenjena u zavisnosti od stepena izraženosti hidrosalpingsa. Odstranjeni jajovodi su histopatološki analizirani u Institutu za patologiju KC Niš.

U najmanje izraženom stepenu hidrosalpingsa, koji je u toku laparoskopije dijagnostikovan u 32 jajovoda, odstranjeno je - urađena je salpingektomia 9 jajovoda, a rekonstruktivna operacija je urađena kod 21 bolesnice. Od 46 jajovoda sa najizraženijim promenama (hidrosalpings III stepena) operacijom je odstranjen 41 jajovod, 5 je okludirano u istmičnom delu, a nijedna rekonstruktivna operacija nije urađena (statistički značajna veza na nivou $\mathrm{p}<0,001$ između stepena hidrosalpingsa i vrste operacije). HP analiza odstranjenih jajovoda pokazuje hroničnu upalu u $84,27 \%$.

Neophodno je koristiti jasne $\mathrm{i}$ iste kriterijume u dijagnostikovanju i napraviti pravilan odabir bolesnica koje će imati korist od operacije hidrosalpingsa, bilo u vidu odstranjenja ili rekonstrukcije jajovoda.

Acta Medica Medianae 2017;56(4):5-10.

Ključne reči: hidrosalpings, laparoskopija, vantelesno oplođenje 